\title{
Jurnal Ilmu Kesehatan Masyarakat
}

(The Public Health Science Journal)

Journal Homepage: http://journals.stikim.ac.id/index.php/jikm

\section{Penggunaan Aplikasi COVID-19 dan Praktik Penerapan Protokol Kesehatan Pencegahan COVID-19 pada Remaja di Indonesia}

\author{
Sri Handayani ${ }^{1}$, Edi Jaya Kusuma ${ }^{2}$, Muhammad Iqbal ${ }^{3}$ \\ ${ }^{1-3}$ Program Studi Sarjana Kesehatan Masyarakat, Fakultas Kesehatan, \\ Universitas Dian Nuswantoro, Semarang \\ Email: yanih61@gmail.com ${ }^{1}$, edi.jaya.kusuma@gmail.com², muhammiq@gmail.com³
}

\begin{abstract}
Abstrak
Remaja merupakan pengguna internet tertinggi dibandingkan dengan kelompok usia lain yang memiliki pengetahuan terbatas mengenai teknologi Kesehatan. Pada situasi pandemi COVID-19 remaja sering dijumpai positif COVID-19 tanpa gejala yang dapat menularkan pada kelompok resiko tinggi lain. Oleh sebab itu penelitian ini bertujuan untuk menganalisa pemakaian aplikasi COVID-19 dan hubungannya dengan praktik protokol kesehatan dalam pencegahan COVID- 19 pada remaja. Penelitian ini menggunakan pendekatan survey dengan menggunakan kuesioner pada google form yang disebar secara online melalui sosial media. Dari hasil penelitian menunjukan bahwa ada hubungan antara penggunaan aplikasi COVID-19 dengan praktik protokol kesehatan sebagai pencegahan COVID-I9 pada remaja (Pv= 0,002; PR: 3,475; Cl: I,598-7,559). Pengguna aplikasi COVID-19 pada kelompok remaja masih sangat minim yaitu sebesar 22,1\%. Diperlukannya upaya peningkatan sosialisasi terkait aplikasi COVID-19 dan telemedicine lain pada kelompok remaja sehingga dapat menjadi salah satu cara edukasi kesehatan pada kelompok remaja.
\end{abstract}

Kata Kunci: Aplikasi COVID-19, protokol kesehatan, remaja.

\begin{abstract}
Adolescents are the highest internet users compared to other age groups who have limited knowledge about health technology. In the COVID-19 situation, adolescents are often found to be positive for COVID-19 aimed to analyze the use of the COVID-19 application and its relationship with the practice of health protocols in preventing COVID-19 in adolescents. This study used a survey approach with a questionnaire on the google form which is distributed online through social media. The research results showed that there was a relationship between the use of the COVID-19 application and the practice of

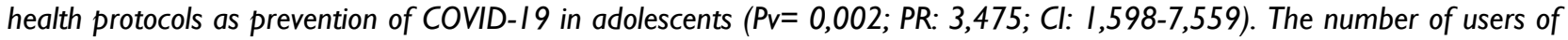
the COVID-19 application in the youth group was still very minimal, namely $22.1 \%$. Efforts are needed to increase socialization related to the application of COVID-19 and other telemedicine in youth groups so that it can become a way of health education for youth groups.
\end{abstract}

Keywords: COVID-1 9 App, health protocol, adolescents. 


\section{Pendahuluan}

World Health Organization (WHO) pada 12 Februari 2020 melaporkan bahwa terdapat sebanyak 45.171 kasus infeksi dengan 115 kasus kematian yang diakibatkan oleh Coronavirus Desease 2019 (COVID-19). COVID-19 hampir sama dengan SARS-CoV khususnya secara genetik. ${ }^{1} \quad$ Berdasarkan data worldmeter pada 7 Desember 2020 dilaporkan bahwa total kasus di seluruh dunia mencapai 67.454.385 kasus dengan jumlah kasus kematian sebesar 1.542.894. Jika dilihat berdasarkan data harian, jumlah kasus infeksi maupun jumlah kematian di seluruh dunia belum mengalami penurunan. Indonesia menempati negara ke-20 dengan kasus COVID-19 tertinggi dengan jumlah kasus $581.550 .^{2}$

WHO memberikan himbauan kepada masyarakat umum untuk melakukan pencegahan penularan COVID-19 melalui berbagai cara antara lain menggunakan masker, menjaga jarak minimal 1 meter, menjaga ventilasi rumah, menghindari kerumuman, mencuci tangan dengan sabun, dan menutup mulut dengan lengan dalam ketika batuk. $^{3}$ Menanggapi hal tersebut, respon secara aktif melalui media online maupun offline terus berkembang secara pesat. Media sosial memberikan kesempatan sebagai media berkomunikasi langsung dengan masyarakat. Seiring diumumkannya COVID-19 sebagai pandemi global, informasi masif tersebar di berbagai jenis sosial media. Di platform Twitter sendiri terdapat sekitar 167.073 twitt tentang topik yang berkaitan dengan pandemi COVID-19 diantaranya penyebab COVID-19, mitigasi dampak, negara, dan kerugian ekonomi. ${ }^{4}$ Hal ini menunjukan bahwa media sosial merupakan media komunikasi efektif tanpa harus adanya interaksi secara langsung kepada masyarakat.

Remaja merupakan kelompok pemakai internet tertinggi di Indonesia. Berdasarkan data kominfo didapatkan bahwa 30 juta anak-anak dan remaja di Indonesia merupakan pengguna internet aktif. Lebih dari 52\% menggunakan ponsel untuk mengakses internet. ${ }^{5}$ Hal ini menunjukan perlu adanya cara baru untuk mengedukasi anak dan remaja secara online terutama dalam hal kesehatan. Hal tersebut juga merupakan kesempatan besar dalam mengembangkan website atau aplikasi mobile terkait dengan kesehatan untuk memberikan informasi yang masyarakat perlukan terkait kesehatan terutama COVID-19. Smartphone merupakan kebutuhan primer dalam kehidupan saat ini. Berdasarkan penelitian sebelumnya, diketahui bahwa jumlah aplikasi terkait COVID-19 yang tersedia baik di playstore maupun App store adalah sebanyak 214 applikasi. ${ }^{6}$

Berdasarkan survey data didapatkan bahwa Indonesia berada pada posisi ketiga setelah India dalam memanfaatkan aplikasi kesehatan yaitu sebesar 57\%. ${ }^{7}$ Berdasarkan data kementerian kesehatan dilaporkan bahwa terdapat 15 juta orang mengakses telemedicine terkait COVID-19 dan hal tersebut mampu mengurangi jumlah pasien yang datang ke rumah sakit. ${ }^{8}$ Selain itu kementerian kesehatan juga menggiatkan penggunaan telemedicine sebagai pilihan utama mengurangi kerumunan di rumah sakit sebagai langkah pencegahan penularan COVID-19. E-health dinilai efektif dan efisien dalam memanfaatkan teknologi komunikasi dan kesehatan. Selain itu WHO juga mempunyai rancangan terkait dengan pengembangan E-health yang menjangkau masyarakat umum dan mengintegrasikan sistem intra dan antar lembaga. ${ }^{9}$

Dalam situasi pandemi ini banyak ditemukan orang tanpa gejala pada usia remaja. Remaja dapat menjadi kelompok yang dapat menularkan kepada kelompok rentan tanpa disadari. Selain itu, remaja merupakan pengguna internet tertinggi dibandingkan dengan kelompok usia lain yang memiliki pengetahuan terbatas mengenai teknologi kesehatan. Oleh sebab itu penelitian ini bertujuan untuk menganalisa pemakaian aplikasi COVID19 yang tersedia pada app store and play 
store dan hubungannya dengan praktik protokol kesehatan dalam pencegahan COVID-19 pada remaja serta menganalisis faktor demografi yang terdiri dari jenis kelamin, tempat tinggal, usia, dan pengetahuan terkait aplikasi COVID-19 dengan praktik protokol kesehatan.

\section{Metode}

Penelitian ini merupakan penelitian survey dengan pendekatan cross-sectional. Populasi dalam penelitian ini adalah remaja usia 16-25 tahun yang menggunakan sosial media di seluruh kota di Indonesia. Pengumpulan data menggunakan kuesioner online melalui google form. Kuesioner terdiri dari 4 kategori yang terdiri dari karakteristik demografi, pengetahuan, penggunaan aplikasi COVID-19, dan praktik penerapan protokol kesehatan terkait COVID-19. Target respondennya adalah usia minimal 16 tahun yang menggunakan sosial media secara aktif. Kuesioner dibagikan melalui link google form melalui sosial media yaitu Facebook dan WhatsApp. Pengumpulan data dilakukan selama bulan OktoberNovember 2020.

Sebanyak 204 responden didapatkan dalam periode penelitian dengan menggunakan google form dengan respon rate sebesar $44 \%$. Berdasarkan sebaran provinsi diperoleh sebagian besar responden berasal dari Jawa Tengah, diikuti dengan Kalimantan tengah, Jawa Timur, Jawa Barat, Kepulauan Riau, NTT, NTB, Sumatra Utara, DKI Jakarta, dan Papua. Data yang diperoleh dikategorikan menjadi beberapa kategori, yaitu tempat tinggal dikategorikan menjadi rural dan urban, usia dikategorikan menjadi $\leq 20$ tahun dan $>20$ tahun, sedangkan pengetahuan kurang (nilai $\leq 25$ ) dan pengetahuan baik (nilai >25). Data diolah dengan menggunakan uji Chi Square untuk menganalisis hubungan antara variabel jenis kelamin, tempat tinggal, usia, pengetahuan tentang COVID-19 dan penggunaan aplikasi COVID-19 dengan praktik penerapan protokol kesehatan pencegahan COVID-19.

\section{Hasil}

Berdasarkan hasil penelitian menunjukan bahwa sebagian besar responden berjenis kelamin perempuan yaitu sebanyak 204 responden $(80,4 \%)$. Sebanyak $57,8 \%$ berusia $\leq 20$ tahun dan $60,3 \%$ bertempat tinggal pada rural area. Sebagian besar memiliki pengetahuan kurang $(78,9 \%)$ tentang pencegahan dan gejala COVID-19. Sebanyak 22,1 \% menggunakan aplikasi terkait COVID-19 pada smartphone mereka. Sebagian besar memiliki praktik penerapan protokol kesehatan terkait COVID-19 yang kurang yaitu sebesar $82,8 \%$.

Praktik protokol kesehatan pencegahan COVID-19 pada responden berjenis kelamin laki-laki lebih baik $(25 \%)$ dibandingkan dengan responden berjenis kelamin perempuan $(15,2 \%)$, namun secara statistik jenis kelamin tidak memilki hubungan dengan praktik protokol kesehatan pada pencegahan COVID-19 $(\mathrm{Pv}=0,540$ dan $\mathrm{CI}=0,235-1,241)$. Secara statistik tempat tinggal tidak memiliki hubungan yang signifikan dalam penerapan protokol kesehatan COVID-19 $(\mathrm{Pv}=1,00$ dan $\mathrm{CI}=0,483-2,134)$.

Responden dengan usia >20 tahun memiliki praktik protokol kesehatan pencegahan COVID-19 yang baik $(22,1 \%)$ dibandingkan dengan usia kurang dari sama dengan 20 tahun $(13,6 \%)$. Secara statistik perbedaan umur dengan praktik protokol kesehatan tidak memiliki hubungan yang signifikan secara statistik $(\mathrm{Pv}=0,159$ dan CI 0,869-3,763). Pada variabel pengetahuan sebagian besar responden dengan pengetahuan baik memiliki praktik protokol kesehatan yang kurang yaitu sebesar 76,9\%. Jika dibandingkan dengan pengetahuan kurang, responden dengan pengetahuan baik memiliki prosentase lebih besar dalam praktik protokol kesehatan yang baik yaitu 23,3\%. Namun secara statistik tidak ada hubungan yang bermakna antara pengetahuan dengan praktik protokol kesehatan pencegahan COVID-19 pada remaja (p-value: 0,334; CI: 0,722-3,766). 
Tabel 1. Distribusi Karakteristik Demografi, Penggunaan Aplikasi Covid-19 dan Praktik Penerapan Protokol Kesehatan COVID-19

\begin{tabular}{llcc}
\hline \multicolumn{1}{c}{ Variabel } & \multicolumn{1}{c}{ Kategori } & $\mathrm{n}$ & $\%$ \\
\hline Jenis kelamin & Laki-laki & 40 & 19,6 \\
Tempat tinggal & Perempuan & 164 & 80,4 \\
& Rural & 123 & 60,3 \\
Tempat tinggal berdasarkan Provinsi & Urban & 81 & 39,7 \\
& DKI Jakarta & 1 & 0,5 \\
& Jawa Barat & 2 & 1 \\
& Jawa Tengah & 179 & 87,7 \\
& Jawa Timur & 4 & 2 \\
& Kalimantan Tengah & 9 & 4 \\
& Kep. Riau & 3 & 1,4 \\
& NTB & 1 & 0,5 \\
& NTT & 2 & 1 \\
Usia & Papua & 2 & 1 \\
Pengetahuan & Sumatera Utara & 1 & 0,5 \\
& S20 tahun & 118 & 57,8 \\
Penggunaan aplikasi COVID-19 & $>20$ tahun & 86 & 42,2 \\
Praktik protokol kesehatan & Kurang & 161 & 78,9 \\
& Baik & 43 & 21,1 \\
& Ya & 45 & 22,1 \\
& Tidak & 159 & 77,9 \\
& Kurang & 169 & 82,8 \\
& Baik & 35 & 17,2 \\
\hline
\end{tabular}

Tabel 2. Analisis Bivariat

\begin{tabular}{|c|c|c|c|c|c|c|c|}
\hline \multirow{3}{*}{ Variabel } & \multirow{3}{*}{ Kategori } & \multicolumn{4}{|c|}{ Praktik Protokol Kesehatan } & \multirow{3}{*}{ P-Value } & \multirow{3}{*}{ PR (CI) } \\
\hline & & \multicolumn{2}{|c|}{ Kurang } & \multicolumn{2}{|c|}{ Baik } & & \\
\hline & & $\mathrm{n}$ & $\%$ & $\mathrm{n}$ & $\%$ & & \\
\hline \multirow[t]{2}{*}{ Jenis kelamin } & Laki-laki & 30 & 75 & 10 & 25 & 0,217 & 0,540 \\
\hline & Perempuan & 139 & 84,8 & 25 & 15,2 & & $(0,235-1,241)$ \\
\hline \multirow[t]{2}{*}{ Tempat tinggal } & Rural & 102 & 82,9 & 21 & 17,1 & 1,000 & 1,015 \\
\hline & Urban & 67 & 82,7 & 14 & 17,3 & & $(0,483-2,134)$ \\
\hline \multirow[t]{2}{*}{ Usia } & $\leq 20$ tahun & 102 & 86,4 & 16 & 13,6 & 0,159 & 1,808 \\
\hline & $>20$ tahun & 67 & 77,9 & 19 & 22,1 & & $(0,869-3,763)$ \\
\hline \multirow[t]{2}{*}{ Pengetahuan } & Kurang & 136 & 84,5 & 25 & 15,5 & 0,334 & 1,648 \\
\hline & Baik & 33 & 76,9 & 10 & 23,3 & & $(0,722-3,766)$ \\
\hline Penggunaan aplikasi & Tidak & 139 & 87,4 & 20 & 12,6 & 0,002 & 3,475 \\
\hline COVID-19 & Ya & 30 & 66,7 & 35 & 17,2 & & $(1,598-7,559)$ \\
\hline
\end{tabular}

Ditemukan bahwa penggunaan aplikasi COVID-19 pada smartphone responden memiliki hubungan yang signifikan terhadap praktik protokol kesehatan pencegahan COVID-19 $(\mathrm{Pv}=0,002 ; \quad \mathrm{PR}=3,475 ; \quad \mathrm{CI}=1,598-7,559$. Hal ini menunjukkan bahwa remaja yang menggunakan aplikasi COVID-19 pada smartphone mereka memiliki kemungkinan 3,475 kali lebih besar untuk mematuhi penerapan protokol kesehatan pencegahan COVID-19 dibandingkan dengan remaja yang tidak menggunakan aplikasi COVID19 pada smartphone mereka.

\section{Pembahasan}

Lebih dari 223 aplikasi COVID-19 diluncurkan di seluruh dunia dengan tujuan untuk mengendalikan pandemic COVID19 saat ini. ${ }^{6}$ Aplikasi terkait COVID-19 banyak tersedia dan mudah diakses melalui smartphone. Beberapa aplikasi dikembangkan oleh pemerintah seperti peduli lindungi, sepuluh rumah aman dan 
lainnya dengan tujuan untuk mengendalikan penularan COVID-19 di masyarakat. Remaja erat kaitannya dengan perkembangan teknologi, namun dalam pemanfaatan serta antusiasme terhadap teknologi yang berkaitan dengan kesehatan masih sangat kurang. ${ }^{10}$ Berdasarkan hasil penelitian didapatkan bahwa sebagian besar remaja $(77,9 \%)$ tidak menggunakan aplikasi COVID-19. Pengembangan sistem pencegahan terkait kesehatan memiliki potensi besar untuk menyasar remaja melalui penyediaan aplikasi kesehatan pada smartphone. ${ }^{11}$

Penelitian Underwood, et al menunjukan bahwa penggunaan aplikasi pada smartphone efektif dalam teknik perubahan perilaku. Penelitian tersebut menunjukkan bahwa $70 \%$ respondennya melaporkan mendapatkan manfaat kesehatan dengan perubahan perilaku yang dibantu oleh aplikasi smartphone. ${ }^{12}$ Selain itu penggunaan aplikasi mobile dalam penilaian resiko individu, kontak tracing, dan monitoring penyebaran COVID-19 merupakan hal yang efektif dan berguna dalam penanganan pandemi. ${ }^{13}$ Penggunaan aplikasi ini akan sangat efektif diaplikasikan didalam masyarakat. ${ }^{11}$

Penggunaan aplikasi tidak hanya bermanfaat bagi pencegahan penyakit saja namun dapat bermanfaat dalam meningkatkan kualitas hidup seperti hasil penelitian Pappot, et al yang menyebutkan bahwa penggunakan aplikasi Kræftværket pada remaja dengan kanker menunjukan bahwa kelompok remaja yang menggunakan aplikasi selama 6 minggu mengalami peningkatan kualitas hidup yang signifikan dibandingkan dengan remaja yang tidak menggunakan aplikasi tersebut. ${ }^{14}$ Dengan banyaknya aplikasi COVID-19 yang tersedia di smartphone perlu didukung dengan kegiatan sosialisasi penggunaan secara masal untuk meningkatkan jumlah penggunaannya terutama pada usia remaja. Secara statistik penggunaan aplikasi COVID-19 pada remaja memiliki hubungan yang signifikan terhadap praktik protokol kesehatan pencegahan COVID-19. Hal ini dapat dijadikan salah satu upaya pencegahan COVID-19 di masyarakat terutama pada kelompok remaja yang menyumbang angka tertinggi untuk kategori tanpa gejala yang justru akan meningkatkan penularan pada kelompok rentan seperti orang dewasa dan anak-anak apabila tidak dilakukan pencegahan.

Variabel demografi tidak memiliki hubungan yang signifikan terhadap praktik protokol kesehatan pencegahan COVID-19 pada remaja pada penelitian ini. Namun berdasarkan penelitian Amoah, et al didapatkan bahwa faktor demografi terutama pendidikan dan socio-ekonomi memiliki korelasi positif terhadap literasi kesehatan. ${ }^{15}$ Dimana literasi kesehatan merupakan faktor lain yang berhubungan dengan perilaku pencegahan. ${ }^{16}$

\section{Kesimpulan}

Pengguna aplikasi COVID-19 pada kelompok remaja masih sangat minim. Oleh karena itu diperlukan upaya peningkatan sosialisasi terkait aplikasi COVID-19 dan telemedicine lain pada kelompok remaja sehingga dapat menjadi salah satu cara edukasi kesehatan pada kelompok remaja. Adanya aplikasi dengan berbagai informasi edukasi kesehatan memiliki peran penting dalam penerapan protokol kesehatan pada kelompok remaja sebagai upaya pencegahan penularan COVID-19 di masyarakat.

Upaya penelitian lebih lanjut tentang dampak penggunaan aplikasi COVID-19 pada remaja terhadap tingkat praktik pencegahan dan implikasinya terhadap penurunan kasus COVID-19 di Indonesia perlu dilakukan. Melalui pemberdayaan karang taruna untuk mensosialisasikan penggunaan aplikasi COVID-19 kepada remaja dengan teknik peer to peer memungkinkan memiliki peluang besar untuk meningkatnya pemakaian aplikasi COVID-19 yang telah disediakan oleh pemerintah didalam aplikasi yang ada di dalam android maupun iphone. 


\section{Daftar Pustaka}

1. Kannan S, Ali, P,A. S.-E. R. M. \& 2020, U. COVID-19 (Novel Coronavirus 2019) - recent trends. europeanreview.org (2020).

2. Worldometer. Coronavirus Update (Live): Cases and Deaths from COVID-19 Virus Pandemic. Worldometers 1 (2020). Available at: https://www.worldometers.info/coronavirus/. (Accessed: 7th December 2020)

3. WHO. Advice for the Public Sector. 1-16 (2020). Available at: https://www.who.int/emergencies/diseases/nove 1-coronavirus-2019/advice-for-public. (Accessed: 7th December 2020)

4. Abd-Alrazaq, A., Alhuwail, D., Househ, M., Hai, M. \& Shah, Z. Top concerns of tweeters during the COVID-19 pandemic: A surveillance study. J. Med. Internet Res. 22, e19016 (2020).

5. Kementrian komunikasi dan Informatika. Riset Kominfo dan UNICEF Mengenai Perilaku Anak dan Remaja Dalam Menggunakan Internet. (2014). Available at: https://kominfo.go.id/content/detail/3834/siaranpers-no-17pihkominfo22014-tentang-risetkominfo-dan-unicef-mengenai-perilaku-anakdan-remaja-dalam-menggunakaninternet/0/siaran_pers. (Accessed: 9th December 2020)

6. Ming LC. et al. Mobile health apps on COVID19 launched in the early days of the pandemic: Content analysis and review. JMIR mHealth and uHealth 8, (2020).

7. Statistika. Indonesia Peringkat ke-3 Global Memanfaatkan Aplikasi Kesehatan | Databoks. (2020). Available at: https://databoks.katadata.co.id/datapublish/2020 /10/13/indonesia-peringkat-ke-3-globalmemanfaatkan-aplikasi-kesehatan. (Accessed: 9th December 2020)

8. Azhar S. Marak konsultasi virus corona, startup telemedicine diakses 15 juta pengguna. (2020). Available https://kesehatan.kontan.co.id/news/marakkonsultasi-virus-corona-startup-telemedicinediakses-15-juta-pengguna. (Accessed: 9th December 2020)

9. Rahim AH. Edukasi Masyarakat Menggunakan Digital Platform. (2019).

10. MacDonell KW \& Prinz RJ. A Review of Technology-Based Youth and Family-Focused Interventions. Clinical Child and Family Psychology Review 20, 185-200 (2017).

11. John Leon Singh, H., Couch, D. \& Yap, K. Mobile Health Apps That Help With COVID-19 Management: Scoping Review. JMIR Nurs. 3, e20596 (2020).

12. Underwood B, Birdsall J. \& Kay E. The use of a mobile app to motivate evidence-based oral hygiene behaviour. Br. Dent. J. 219, E2 (2015).

13. Kondylakis H. et al. COVID-19 Mobile Apps: A Systematic Review of the Literature (Preprint). J. Med. Internet Res. 22, (2020).

14. Pappot H. et al. Health-related quality of life before and after use of a smartphone app for adolescents and young adults with cancer: Prepost interventional study. J. Med. Internet Res. 21, (2019).

15. Amoah P. A. \& Phillips, D. R. Sociodemographic and behavioral correlates of health literacy: a gender perspective in Ghana. Women Heal. 60, 123-139 (2020).

16. Fleary SA, Joseph P \& Pappagianopoulos, J. E. Adolescent health literacy and health behaviors: A systematic review. J. Adolesc. 62, 116-127 (2018). 